\title{
Christelijke literatuur in Nederland aan het einde van de 20e eeuw
}

\author{
Hans Werkman \\ Amersfoort \\ NEDERLAND
}

\begin{abstract}
Christian literature in the Netherlands at the end of the 20th century
\end{abstract}

Christian literature implicitly or explicitly incorporates the idea of hope in Christ. Literature has an inherent ethical element and this element can also bear a Christian character. Following upon the ergocentric literary approach of the sixties more room has recently been given to "moralizing the literary domain as a corrective of the aestheticising of literature" (J.J.A. Mooij). Despite this trend Christian literature has not flourished in secularized Dutch society. Internally, Christian literature is endangered by Christian readers expecting a one-dimensional message; externally Christian literature as such is not recognized sufficiently by literary critics having no ties with or knowledge of christianity.

The existence of Christian literature in the Netherlands is, however, evident at the end of the 20th century. Although narrative prose inspired by the Christian message has not produced remarkably many novels, the novels of Mance ter Andere have definitely attracted attention. Christian poetry, however, is flourishing (Inge Lievaart, Guillaume van der Graft, Koos Geerds).

In this essay it is contended that Christian literary critics have the advantage of being able to interpret and fathom biblical elements in literature, thus adding an ethical dimension to the evaluation of literature.

\section{1. "Christelijke literatuur bestaat niet"}

Enkele citaten uit de jaren tachtig geven de omstreden positie aan van de modeme christelijke literatuur in Nederland. De literatuurcriticus Wim Zaal schreef: "De christelijke literatuur heeft zichzelf van de kaart geveegd" (Zaal, 1982). Jacques Kruithof, literatuurhistoricus, meende: 
Het Vijfstromenland van de verzuilde literatuur [heeft] zijn einde gevonden. Opvolgers van confessionele woordvoerders als Anton van Duinkerken en C. Rijnsdorp hebben zich niet aangediend, en mochten er essayisten zijn die in hun trant schrijven, dan worden zij toch buiten hun subcultuur niet langer opgemerkt (Kruithof, 1986:176).

Henk van der Ent, dichter en essayist, tenslotte: "Christelijke literatuur bestaat niet" (Van der Ent, 1990:50).

Dit laatste citaat is tevens de titel van een essay, in september 1989 opgenomen in een themanummer van het christelijk literair tijdschrift Woordwerk. In dit themanummer over "christelijke literatuur tegen het einde van de twintigste eeuw" was dit Paardje van Troje bewust toegelaten: "Christelijke literatuur bestaat niet". Van der Ent, ooit als de dichter Anton Ent begonnen binnen de christelijke literatuur, nam overigens iets van zijn statement terug. Ik citeer: "Het predikaat Christelijk wil ik geven, maar dan met een hoofdletter, aan liederen en gedichten die Christus bij name noemen en Hem als bevrijder belijden." Ik maak hieruit op dat bij Van der Ent wèl christelijk is "De disgenoten" van Ida Gerhardt, waarin Christus expliciete namen draagt:

Waar aan de witte dis
uw teken wordt beleden
verschijnt Gij - "u zij vrede"
gij Brood - gij Wijn - gij Vis

(Gerhardt, 1992:266).

Maar een gedicht waarin de christelijke noties impliciet verwerkt zijn, kan volgens hem niet christelijk heten. Niet dus van Ida Gerhardt de regels:

De maartse regen had het 's nachts gedaan:

daar stond zijn doopnaam, in sterkers gezaaid

(Gerhardt, 1992:494).

Toch vormen deze regels het slot van het gedicht "Pasen". Maar deze titel hoeft niet per se te verwijzen naar de opstanding van Christus. "Pasen" kan, aldus Van der Ent, ook door een lezer ervaren worden als een gedicht over "blijdschap om wat de aarde geeft", over een doopnaam in de zin van "een groeiende naam, fris, nieuw, levend", zonder expliciet christelijk perspectief (Van der Ent, 1980:39). In dat geval is het gedicht niet christelijk, omdat de lezer het als niet-christelijk ervaart. Christelijk zou het voor een moment worden als een ander lezend individu de begrippen "doopnaam" en "Pasen" vult met christelijke inhouden. De inhouden komen vooral uit de lezer, ze zijn niet voorbehouden aan het gedicht. Aldus ongeveer de visie van Van der Ent. 
Deze ervarings-exegese van literatuur lijkt mij verwant aan de ervaringstheologie, waarin al het geloven van onderaf komt, vanuit het subject van de mens, en niet vanuit een van bovenaf geopenbaard geloofsobject. Naar mijn mening houdt Van der Ent te weinig rekening met een objectieve inhoud van literatuur, een inhoud die mede bepaald is door de context, waartoe ook het andere werk van die bepaalde dichter behoort. Zo gezien, kan men "Pasen" van Gerhardt toch wel een christelijk gedicht noemen. Een schijnbaar-christelijke tekst valt dan voor de objectieve lezer al gauw door de mand, zoals het gedicht "Johannes 12:44" uit de bundel Bijbelplaatsen van Jan Kuijper:

Die in mij gelooft, gelooft in mij niet, en ook de rest niet. Jammer is dat wel, ik hang hier toch maar in mijn blote vel

(Kuijper, 1983:30).

Ik ontken natuurlijk niet dat er legaal verschil in lezerservaring bestaat, maar meestal houdt de inhoud deze verschillen binnen grenzen, althans zolang men op niet-postmodemistische wijze het begrip "inhoud" relateert aan werkelijkheidservaring binnen een tekst.

\section{Definities van christelijke literatuur}

Zo is ook het bestaan van christelijke literatuur in de jaren negentig mogelijk. Het begrip "moderne christelijke literatuur" vraagt om een definiëring. We hoeven dit wiel niet helemaal opnieuw uit te vinden, en daarom haal ik eerst enkele oude definities aan.

In 1932 schreef de dichter Willem de Mérode aan zijn vriend Barend de Goede: "Christelijke litteratuur is litteratuur die Christus als den Heer belijdt. En dat kan alleen, als de auteurs Hem zelf zoo kennen en belijden." Wat aan deze definitie ontbreekt, is een omlijning van het begrip "literatuur" (Werkman, 1983:221).

Deze definitie lijkt veel op die van W.A.P. Smit, zes jaar eerder gegeven en later veel geciteerd: "Christelijke kunst is kunst van christenen" (Smit, 1926:344; 1991:11-12). Smit was ertegen om versjes en romans vanwege hun vrome inhoud in te lijven bij de christelijke literatuur. Maar anderzijds: als een kunstenaar echt christen is, dan komt het christelijke bijna automatisch mee in zijn kunst. Smits definitie was een pleidooi voor zowel artistieke als christelijke oprechtheid. Ook hy definieerde echter niet het begrip "kunst" of "literatuur".

$\mathrm{Na}$ veel getheoretiseer over het verschil tussen christelijke literatuur en literatuur van christenen formuleerde Bert Hofman in 1984 een nieuwe definitie. Hij sprak van "bijbelse literatuur": "Bijbelse literatuur is die 
literatuur waarin de persoonlijke situatie van de auteur versmelt met toepasbare elementen uit de Heilige Schrift, zó dat deze hem blijvend inzicht verschaffen en in de concrete verwoording een structurele plaats krijgen" (Hofman, 1984:27-28). Een voordeel van deze definitie is dat het begrip "christelijk" omlijnd wordt. Een nadeel, dat het "blijvend inzicht" van een auteur merkwaardigerwijs deel uitmaakt van een definitie van literair werk. Weer ontbreekt echter een omlijning van het begrip "literatuur". In de definities van De Mérode en Smit zat hier geen artistieke niveauverlaging achter. Maar bij Hofman is dit, naar ik vrees, wel het geval. Hij wil binnen de kring van literatuur bijvoorbeeld ook de clichématige pastorale poëzie een legale plaats geven.

Zelf definieer ik de drie woorden in het begrip "moderne christelijke literatuur" graag apart, maar wel in elkaar hakend. Als volgt:

* Christelijke literatuur is literatuur waaruit expliciet of impliciet blijkt dat er hoop is omdat Christus is opgestaan; de weg naar de hoop gaat menigmaal via wanhoop en twijfel.

* Christelijke literatuur moet kunstzinnige verfijning en originaliteit bezitten.

* Moderne christelijke literatuur bemoeit zich met de problemen van haar eigen tijd en zal in de tweede helft van de twintigste eeuw daardoor vaak geëngageerde literatuur zijn.

René van Woudenberg zoekt de taakstelling van een christen-literator allereerst in het positieve: "een kunstenaar voldoet aan zijn roeping inzoverre hij op enigerlei wijze bijdraagt aan de shalom, de Godsvrede." Dit is één kant van de zaak. De andere is dat ook een christen-literator onafgebroken als Picasso aan zijn afschuwelijke maar waarachtige Guernica schildert. Maar ook daarvoor heeft Van Woudenberg oog: "het kunstwerk deelt volop in de menselijke conditie: het deelt in onze grandeur, maar ook in onze misère" (Van Woudenberg, 1989:10).

Christelijke literatuur die zich opsluit in zichzelf, vervalt tot wensvervullende lektuur. Grote christelijke verwachtingen zijn gericht op samenleving en cultuur en liggen daardoor altijd in de vuurlinie, ondergaan het wangeloof en de twijfels van een modeme vaderloze wereld, ervaren op weg naar de godsverlichting een grote mate van godsverduistering. Christelijke literatuur schuurt zich aan de tijd, loopt daarbij wonden op en maakt zich mede daardoor geloofwaardig. Christelijke literatuur mag niet bij voorbaat geruststellen. Ze moet ook verontrusten en onveilige literatuur zijn. Echter niet tot het bittere einde, want aan christelijk geloof is inherent dat het uiteindelijk deel heeft aan 
de shaloom. Die vrede kan in literatuur nooit goedkoop gestolen zijn, die moet meestal bevochten worden op het wangeloof. ${ }^{\text {I }}$

\section{De ethische factor van literatuur}

Christendom is per definitie ethisch van karakter. Mag men ook het esthetische verenigen met een ethische factor? Ik ken nauwelijks kunst zonder ethische factor. Ruimer: alle menselijke handelen heeft een ethische component, omdat de mens bedoeld is als een verantwoordelijk wezen. Sterker: omdat de mens een verantwoordelijk wezen is, heeft de ethiek het laatste woord, en "dat geldt voor alle menselijke handelen, van voetballen tot filosoferen toe" (Van Doome, 1975).

Verantwoordelijkheid is, ook in artistieke zin, geen besmet woord. De Nederlandse beweging der Tachtigers (Kloos, Perk) heeft de kunst jarenlang opgezadeld met het idee dat kunst bestond om zichzelfswille, in de ivoren toren van de artisticiteit, en die toren had geen vensters naar buiten, men zag in die toren geen mensen, maar alleen kunst als idee, geen kunst met een inhoud op mensen gericht.

De Vlaamse romanschrijver Mamix Gijsen heeft in de jaren zestig gezegd: "Kunst zonder ethische inhoud is een hond die in zijn eigen staart bijt, die krijgt nooit iets beters te pakken." In diezelfde jaren zestig mocht er echter in de literatuurkritiek geen ethiek binnensluipen. Het was de tijd van de kunstzinnige inteelt. Alleen het literaire werk bestond, alleen letters op papier, die met het pincet van de close-reading ontleed dienden te worden. De bloedwarme schrijver en de bloedwarme lezer behoorden in dit bedrijf absent te zijn. Deze ergocentrische benadering van literatuur ontkende een ethische component. Romans werden beoordeeld uit zogenaamd "zuiver literair standpunt". De protestants-christelijke literatuurcriticus C. Rijnsdorp noemde dit al in de jaren zestig "een hogere vorm van scheelzien" (Rijnsdorp, 1966:87).

In 1973 viel J.J.A. Mooij hem in een artikel in De Gids zakelijk bij. Een literair waardeoordeel kan volgens Mooij mede berusten op een moreel argument. Hij distancieerde zich van een bloedeloos "zuiver literair standpunt" in de literatuurkritiek en hij formuleerde een reeks invalshoeken voor een literatuurcriticus:

1 De Zuidafrikaanse roman Juffrou Sophia vlug vorentoe door Berta Smit (1993) beantwoordt in vele opzichten aan de normen die ik stel aan een moderne literaire christelijke roman. 
* De intentionele benadering, waarbij het vooral gaat om de bedoeling van de auteur.

* De emotivistische benadering, waarbij de criticus vertelt wat het boek hem gedaan heeft.

* De realistische benadering, waarbij de criticus een tekst beoordeelt op werkelijkheidsgehalte.

* De morele benadering, waarbij hij een boek meet naar zijn eigen levensbeschouwelijke, dus ook religieuze, normen.

* De vernieuwingsbenadering, waarbij hij speurt naar het nieuwe, het verrassende, het andere in het boek.

* De structurele benadering, waarbij hij ingaat op de opbouw van het kunstwerk en op de werkwijze van de auteur (Mooij, 1979:253-278; Bakker, 1989:115-123).

Deze reeks geeft een duidelijke verruiming vergeleken bij de ergocentrische benadering. Mooij luidde daarmee een wending in: de ethische dimensies begonnen weer in de literatuur geaccepteerd te raken. Twintig jaar later verdedigt hij dit standpunt nog steeds: het ethische gezichtspunt kan in een aantal opzichten voorrang hebben boven het esthetische. Literatuur is immers een vorm van handelen, zegt hij, en dus onderworpen aan een morele beoordeling. Bovendien is menigeen gespitst op de vraag wat literatuur bijdraagt tot ons welzijn. Dit is een ethische vraag (Mooij, 1992:70-75). Mooij pleit voor "moralisering van het literaire gebied (...) als correctie op de esthetisering ervan" (Jansen e.a., 1994:21).

De Nederlandse literatuurcriticus en huidige staatssecretaris van cultuur, Aad Nuis, accentueerde in 1989 in zijn gastcolleges aan de Universiteit van Groningen de ethische factor van literatuur. Hij zei:

Literatuur doet een aanslag op onze overtuigingen, onze verbeelding, onze ziel. Ze wil ons veranderen en daagt uit tot een reactie.

Een boek is een werktuig, een wapen, een gevaar dat de ziel in wil. Ontbreekt het besef daarvan en een reactie erop, dan lijkt een bespreking op een beschrijving van een bijl als een siervoorwerp in een vitrine in plaats van als een werktuig waar je hout mee hakt. Hoe de bijl in elkaar zit, wordt pas interessant voor wie wil weten hoe het komt dat de inslag in het hout zo krachtig was, of zo krachteloos (Nuis, 1989:66 en 49). 
Terecht kwam men terug van de overwaardering van literariteit. Literatuur gaat ergens over, neemt een standpunt in, of het nu existentialistische literatuur is (W.F. Hermans) of mystiek-humanistische literatuur (Maarten ' $t$ Hart) of christelijke literatuur (Mance ter Andere). Een inhoud kan nooit literariteit alleen zijn. Bovendien: de hele mens leest, niet alleen een afgesplitste estheet in de mens, of een afgesplitste realist in een mens, en ook niet een afgesplitste moralist of ethicus in de mens. Literatuur heeft inhoud, en inhoud is drager van ook realistische zaken, ook emotivistische zaken, ook structurele zaken, en vooral: ook ethische zaken.

Hermans en Mulisch verkondigen in hun romans het deficit van de mensheid. Kellendonk verkondigt, hoe dan ook, mystieke waarden, Bernlef verkondigt de humaniteit van mensen. Als schrijvers geen waarden of onwaarden mee te delen hebben, vertegenwoordigen ze geen inhoud en betekenen ze niets. Ik ben het daarom met Mooij, met Rijnsdorp, met Nuis en anderen eens dat ook de ethiek een duchtig woord mee moet spreken in de beoordeling van een literair werk.

Men zou denken dat deze vermieuwde aandacht voor de ethiek in het voordeel werkt van de aandacht voor christelijke literatuur. Deze is immers per definitie geladen - impliciet of expliciet - met christelijke ethiek. Maar nee. De herwonnen ethiek maakt kennelijk deel uit van een wereld waarin het christelijk geloof aan het voorbijgaan is. De grote pers in Nederland heeft nauwelijks aandacht voor christelijke literatuur, of het moest zijn voor de fraaie Gezellebiografie van Michel van der Plas die bijna de prestigieuze AKO-prijs haalde, en natuurlijk voor christelijk-literaire ruzietjes. In Vlaanderen ligt het anders, daar wordt het rooms-katholieke dagblad De Standaard nog breed gelezen. In Nederland is, sinds de ontkerstening van het dagblad Trouw, geen grote christelijke krant meer. De kleinere - Reformatorisch Daghlad en Nederlands Dagblad - worden nauwelijks buiten de eigen aanhang gelezen.

\section{Overmaat aan religie}

Op de christelijke literatuur werken mijns inziens twee bedreigende processen in. Het ene bedreigt haar artisticiteit, het andere haar christelijkheid. De kwantiteit van de geloofsfactor namelijk kan haar als literatuur minder geloofwaardig maken, en de secularisatie dreigt haar te ontkerstenen.

Kort over het eerste. Een overmaat aan religie maakt de boodschap van een tekst topzwaar. Die boodschap deelt zich onmiddellijk aan de lezer mee. Herlezing van pastorale verhalen en gedichten tilt geen nieuwe vondsten naar het licht. Ze hebben naar hun eigen aard een belangrijke taak. Niemand mag eenvoudig en duidelijk pastoraat minachten, ook niet als dit pastoraat gebracht wordt door dichters of verhalenschrijvers. Maar literatuur is het niet. De 
boodschap is hier zo belangrijk dat deze de witte plekken van de literaire setting niet verdraagt. De programmatisch-religieuze gedichten van de Vlaming Anton van Wilderode zijn bijvoorbeeld aanzienlijk zwakker van literaire kwaliteit dan de gedichten die los van zijn priesterschap-als-ambt zijn ontstaan. Eéndimensionale boodschappen verdragen zich niet goed met literaire vormkracht, want artisticiteit is naar haar aard meerdimensionaal. Dit is nauwelijks een punt van discussie tussen een christen-literatuurbeschouwer en zijn seculiere collega. Het is wel een punt van discussie met de achterban van christelijke lezers.

\section{Secularisatie}

Opmerkelijk is echter dat de seculiere collega-literatuurcriticus in Nederland een flinke stap verder gaat. Als hij in een tekst iets belijdends-christelijks ontmoet, is dit voor hem in het algemeen een belemmering om zo'n tekst bij de literatuur in te lijven. Het is een typisch verschijnsel van de tweede, geseculariseerde helft van de $20 \mathrm{e}$ eeuw.

Hans Ester schreef vorig jaar in een verontrust artikel "Cultureel geheugenverlies": "Als een literair werk als christelijk bestempeld wordt, betekent dat voor dat boek hooguit erkenning binnen een gesloten circuit van gelovigen en een doodvonnis daarbuiten" (Ester, 1994). Ik ben het daar goeddeels mee eens, al zijn er zeker uitzonderingen. Van de antenne om geloofsseinen op te vangen is in de geseculariseerde literatuurkritiek maar een stompje overgebleven. Dit bleek heel duidelijk in de neersabelende kritiek op de novellenbundel De inktvis van Oek de Jong, een boek vol christelijk- en oosters-mystieke motieven, die men eenvoudigweg het oor niet leende, omdat er een gat in dat oor zat, het gat waaruit de kennis en ervaring van religie verdwenen was. In de grote pers was het alleen Jaap Goedegebuure die de moeite nam in Oek de Jongs gedachtenwereld binnen te dringen. Maar Goedegebuure is in het christelijk geloof opgevoed en staat daar op zich niet rancuneus tegenover, ook al rekent hij zich niet meer tot de gelovigen (Goedegebuure, 1993; Werkman 1994).

Deze onwilligheid om zich serieus in te leven in christelijke patronen, werd in 1953 al door Bomhoff gesignaleerd. Hij sprak van de "kleine terreur der neutraliteit", die de christelijke literatuur negeerde omdat ze vond dat de inspirerende kracht van de christelijke idee maar klein was (Bomhoff, 1953/1988).

Eeuwenlang is kunst christelijk geïnspireerd geweest. Het postchristelijke tijdperk van na 1965 heeft gebroken met dit verleden. Niet alleen het geloof is goeddeels verdwenen, ook de aanwezigheid van kennis over geloofsmotieven. W.A.P. Smit kon in de jaren zestig aan de Universiteit van Utrecht niet zonder meer de bijbelse drama's van Vondel gaan behandelen, hij moest eerst de 
onbekende verhalen over Jozef en Jefta vertellen. Jaap Goedegebuure geeft momenteel aan de Katholieke Universiteit Brabant bijbelles. Het onderwijs aan 6- tot 18-jarigen laat het afweten. Ook op christelijke scholen is bijbelkennis minimaal, laat staan doorleefd. In de Nederlandse culturele maatschappij is de naam God praktisch inhoudloos geworden.

Het gevolg daarvan is natuurlijk dat literatuurcritici, uit deze scholen afkomstig, het moeilijk vinden te reageren op christelijke kunst. Pas na de Rijnsdorpprijs voor Guillaume van der Graft kwam er in de seculiere pers enige aandacht voor de poëzie van Van der Graft. Zijn zoon Benno Barnard zei: Als mijn vader dat verdoemelijke vak van dominee niet had uitgeoefend, had hij allang grote literaire prijzen gehad. De Verzamelde gedichten van Jan Willem Schulte Nordholt - poëzie van statuur, verschenen in 1989 - werden niet besproken. De Verzamelde gedichten van Willem de Mérode, verschenen in 1987, evenmin. Literatuur die bij de christelijke uitgeverij Kok in Kampen verschijnt, wordt door de literatuurkritiek weggeselecteerd op het uitgeversvignet. Maar ook christen-dichters die in het Amsterdamse seculiere circuit uitgegeven worden en bij wie wel degelijk belijdend-christelijke elementen te vinden zijn (Lenze Bouwers, Koos Geerds, Harmen Wind) krijgen slechts mondjesmaat aandacht. De van oorsprong christelijke dichter Anton Ent kreeg pas alle schijnwerpers op zich gericht en oogstte pas waardering toen hij zich in travestie vertoonde als de dichteres Marieke Jonkman.

Gerrit Komrij is in zijn zeer veel verkochte poëziebloemlezing uit 1987 uitermate gierig tegenover christelijke literatuur van de $19 \mathrm{e}$ en $20 \mathrm{e}$ eeuw. Hij nam natuurlijk ook dichters op wier werk aanzienlijke christelijke thema's bevat, maar juist deze thema's negeerde hij systematisch. Dit betekent dat in deze bloemlezing wel een ruim bemeten plaats is voor Gezelle, Achterberg, Gerhardt, De Mérode, Gossaert, Van der Graft, maar dat van hen geen enkel gedicht met een christelijk thema is opgenomen. Alleen van Nijhoff is "De moeder de vrouw" geplaatst, met die laatste regel "Prijs God, zong zij, zijn hand zal u bewaren". Komrij heeft op deze manier grote dichters die niet los te denken zijn van hun christelijke thema's, postuum gecoupeerd voor een geseculariseerd publiek. Dit is geestelijke manipulatie (Komrij, 1987; Werkman, 1989:94-95).

In deze sfeer is het voor de modeme christelijke literatuur niet gemakkelijk om het hoofd boven de hekken van het eigen terrein uit te steken. Desondanks: ze bestaat en ze betreedt hier en daar ook het Amsterdamse circuit van uitgevers.

lk wil tenslotte een rondgang maken langs de drie gebieden van de moderne Nederlandse christelijke literatuur: de poëzie, het verhalend proza en de essayistiek en literatuurkritiek. 


\section{Poëzie}

De poëzie is het meest vitale onderdeel van de huidige christelijke literatuur in Nederland. Het valt op dat van de stuk of tien belangrijke levende christelijke dichters er slechts twee bij een uitgever zitten met een overwegend christelijk boekenfonds. Dat zijn Frank Daen en Inge Lievaart, beiden 75+. Inge Lievaart is al vele jaren meesteres in de Japanse haiku, een niet-christelijke vorm natuurlijk, die zich volgens Lievaart ook niet leent voor expliciet christelijke inhouden, maar wel zijn vele van haar haiku verwant aan haar geloof. Ze verwacht het koninkrijk Gods ook in haiku-vorm. Als volgt bijvoorbeeld:

\section{Zonder vertragen \\ gaat het water zijn omweg \\ met haast en geduld}

(Lievaart 1994:8).

Haar generatiegenoten, de historicus Schulte Nordholt, en de theoloog en hymnoloog, Van der Graft, hebben een groot aandeel in de huidige liedcultuur van de protestantse kerken in Nederland en publiceerden ook andere poëzie. Bij beiden staat in hun laatste bundels geloven in het teken van de aarzeling, van de godsverberging, die ze toch niet willen accepteren. Van der Graft schrijft over God: "Angst is een hinderlaag on u heen" (Van der Graft, 1993:7). De in augustus 1995 overleden Schulte Nordholt brengt het wijkende godsbesef van onze tijd onder woorden: "Ik hunker naar de god die er niet is" (Schulte Nordholt, 1994:40). Ook de predikant Jaap Zijlstra, 60+, leverde vele liedteksten en publiceert de laatste jaren behalve natuurpoëzie ook speelse liefdespoëzie:

\section{Ben ik in je gretige ogen \\ een bidsprinkhaan, zo traag, wat ik je bidden mag, blijf komen, ik zie je zo graag}

(Zijlstra, 1991:39).

De dichters Koos Geerds, Lenze L. Bouwers, Harmen Wind en Henk Knol zijn van een op Zijlstra volgende generatie. De eerste drie publiceren bij de nietchristelijke uitgevers Querido en Arbeiderspers.

Bouwers introduceerde enkele bundels lang de rondeelvorm opnieuw in Nederland. Zijn poëzie beweegt zich veelal tussen aards verval en bovenaardse vervulling.

de luiaard heeft zich in de tijd vergist want duizend wordt in één veeg uitgewist; de ware tuinman keurt met brede lach 
een appelboompje voor de jongste dag

(Bouwers, 1985:39).

Harmen Wind is, veel meer dan Bouwers, in gevecht met traditionele geloofswaarheden.

Sedert wij beter weten vallen
mussen zinloos van het dak.
Wij leren onze kat wat ze
niet mag, geloven nog in
veiligheid, hopen op ons gemak

(Wind, 1994:32).

Lijden aan de tijd is een vast thema in het werk van Henk Knol. De fraaie loftuitingen van het bijbelse Hooglied, in de $17 \mathrm{e}$ eeuw door Revius bewerkt, roepen bij Knol anti-regels op.

[Ze] weigert borsten met zich om te dragen;

hun rimpel valt tussen haar ribben weg.

Ze telt de dagen af waarop ze bloeden moet

(Knol, 1994:11)

Hilbrand Rozema (geb. 1971) is de jongste van de huidige talentvolle christendichters. Hij weet scherp een sfeer van heil en onheil op te roepen.

In dat Egyptisch duister stelden jij en ik, mijn vriend, ons plotseling de Jacobsladder voor.

Het scherpte ons gehoor.

Zeker vijf, zes uilen vlogen over, zuiver geluidloos en wit in onze lichtkegels.

Toch even die huiver; klemvast in slaapzakken geritst waren we prooien

om van te dromen

(Rozema, 1993:34).

Rondom de dichter Koos Geerds heeft zich in 1994 een typisch protestants rumoer afgespeeld. Hij publiceerde in een poëzienummer van Maatstaf zijn lange gedicht "Gods element". In de christelijke pers riepen zijn water- en vocht-metaforen weerstanden op.

Hij [God] stuurt het zaad met voorbedachte rade, maakt dat het vrijen lekker gaat, zijn top bereikt;

Hij pootjebaadt in oceanen, jaagt orca's op, (...) 
speelt met een ijsberg kiekeboe, kietelt

een walvis tussen $z^{\prime} n$ baleinen (...)

God heeft het land aan de woestijnen, aan droge, saaie, humorloze praat, aan preken waar geen letter poëzie in staat; Hij houdt van avontuur, muziek en donderjagen diep in zijn hart is God een ouwe zeepiraat

(Geerds, 1994:84-85).

Dit lofgedicht op God kreeg z'n felle voorstanders op basis van gelovige en literaire echtheid, en z'n even felle tegenstanders op basis van traditioneel vormgegeven eerbied en fatsoen. ${ }^{2}$ Binnen de niet-christelijke redactie van Maatstaf werd het vers herkend als uiterst vitaal. Koos Geerds is waarschijnlijk het beste bewijs dat christelijke poëzie de muren van de christelijke literaire gemeente kan overstijgen. Wel moet gezegd worden dat de (gast)redacteuren van het Maatstafnummer zeer goed bekend waren met het christelijk geloof. Het postmodernistische tijdschrift Zoetermeer had het gedicht ongetwijfeld geretourneerd.

\section{Verhalend proza}

In 1993 heeft het literair tijdschrift Bloknoot een discussie op gang gebracht over de vraag waarom er de laatste tien, vijftien jaar zo weinig goed literair christelijk verhalend proza is verschenen. Hier geen grote romanschrijvers in de trant van A.F.Th. van der Heijden, Maarten 't Hart, Connie Palmen, Tessa de Loo; geen literaire schrijvers die om de paar jaar hun nieuwe roman klaar hebben. Hoe komt dat?

Dirk Zwart, redacteur van Bloknoot, giste met anderen naar de oorzaken (Zwart, 1993a:34-39, 1993b:68-78). Te weinig talent? Te weinig idealisme om een aantal beginjaren van droog brood te willen leven, zoals je dat ziet bij doorbrekende romanschrijvers als Thomas Rosenboom en Willem Jan Otten? Is het eigenlijk wel mogelijk het geloof te integreren in een verhaal dat onder literaire spanning staat? Nee, zei de niet-christelijke romanschrijver Willem van Toom, want een christen is er zeker van dat God zijn leven leidt volgens

2 De discussie over dit gedicht werd gevoerd in Nederlands Daghlad, 5 juni en 23 juli 1994 en in Bloknoot, christelijk literair tijdschrift, nr. 9, aug. 1994, p. 121-129 en nr. 11, febr. 1995, p. 69-71). De dichter Ed Leeflang, gastredacteur van Maatstaf waarin het gedicht was opgenomen, schreef me (met kennelijk enige overdrijving): "Het vitaalste christelijke gedicht sinds Vondel. In Nederland dan, anders doen we Gezelle tekort" (4 juni 1995). 
een vast plan, en dus mist hij de voorwaarde tot scheppen, want scheppingsdrang komt vooral voort uit de wanhopige vraag waartoe al het lijden dient. Wie gelooft dat de zingeving van het leven vast ligt in God, zei R.L.K. Fokkema, heeft de zoektocht naar een andere zingeving op het niveau van verhaal of gedicht niet nodig. Daarom bestaat er geen goed christelijk literair proza (Van der Ent, 1986).

Ik vind dit een te enkelvoudige situatiebeschrijving. In de eerste plaats hebben niet-christelijke schrijvers wel meer aandriften om te schrijven dan alleen het wanhopige protest tegen een onoplosbare verscheurdheid. Zie het werk van J. Bernlef, Koos van Zomeren, Maarten 't Hart, Leo Pleysier. In de tweede plaats staat het niet bij voorbaat vast dat christenen in principe spanningsloos leven en dus verhalen schrijven met een zoete afloop. Ze vergeten dat vele fel levende christenen zich onophoudelijk verwonden aan onoplosbaar lijden, aan godsverduistering, aan starheid en conservatisme in kerk en christelijke instituten.

Enkele Nederlandse christen-schrijvers van de laatste tien jaar hebben vanuit zo'n verscheurdheid romans en verhalen geschreven. Misschien was het gebrek aan groot talent (niet: groot gebrek aan talent!) waardoor ze onopgemerkt bleven buiten hun christelijke publiekskaders. Maar ook door het eigen christelijke publiek werden ze niet naar herdrukken gevoerd.

Ik zoek naar oorzaken. In de eerste plaats denk ik dat het christelijke leespubliek literair te weinig eisen stelt en de christelijke serieroman met een voorgeschreven happy ending prefereert. In de tweede plaats accepteert het kerkelijk meelevend publiek het maar nauwelijks dat een christen-auteur vuile was buiten hangt. Een literaire christen-auteur - naar zijn aard kritisch ingesteld - zal zich op z'n tijd geëngageerd willen gedragen ten aanzien van zijn eigen christelijke milieu. Een hoera voor Jezus Christus kan ook inhouden dat de schrijver ramen van heilige huisjes wil ingooien. Het publiek - veelal behoudzuchtig genietend van rustgevende clichés - zegt: schrijver, wrik ons niet los uit onze gevestigde orde. Een geëngageerd christen-auteur stuit op kerkelijk-maatschappelijke weerstanden. Voor dichters is dat minder erg. Een dichtbundel wordt toch alleen maar door de happy few gelezen. Maar verhalend proza is naar zijn aard minder elitair, minder cryptisch en rekent op meer publiek. Te veel christenen houden van "droge, saaie, humorloze praat", van "preken waar geen letter poëzie in staat" en niet van "avontuur, muziek en donderjagen" (Koos Geerds). De kerk is nu niet de plek bij uitstek waar speelsheid, ironie en satire graag ontvangen worden. Bovendien: "Binnen de geloofsgemeenschappen betreffen de prioriteiten veelal kerk en politiek, de literatuur (en de kunst in het algemeen) blijft een randverschijnsel. Daardoor mist er een ideale receptieve sfeer" (Bakker, 1993:71). 
Toch ontdekte Dirk Zwart tussen 1980 en 1992 nog elf werken van tien auteurs, die hij tot de Nederlandse christelijke moderne verhalende literatuur rekende. Ik schuif wat op, naar de periode 1985-1995, en kom ook tot een lijstje met elf werken van negen auteurs. Chronologisch:

* Dingeman van der Stoep schrijft in De dader ligt op Meerzijn (1985) halfironisch over de botsing tussen twee kerkelijke generaties.

* Auke Jelsma verbindt in Ballingen (1985) het hart van de Middeleeuwen aan een visie op God in onze tijd.

* Lenze L. Bouwers was de eerste die met Lieve vader, vuile schurk (1988) het probleem incest tot onderwerp van een jeugdroman maakte.

* Een avond in de polderkamer (1989) van Hans Werkman bevat verhalen over het thema "vervreemding". Enkele ervan zijn gerelateerd aan zijn biografische studies over de dichter Willem de Mérode.

* Rijke de Wolf schreef met Sapuru (1992) zijn debuut, een interessant gecomponeerd heidens verhaal dat op Irian Jaya speelt.

* Cornelis Goslinga blijkt een verteller van het brede, heldere, sociaal geëngageerde Antilliaanse verhaal te zijn in Sjons en slaven (1992) en Een zweem van weemoed (1993).

- Meint R. van den Berg, een veelschrijver die de vorm van zijn werk meestal te kort laat rijpen, schreef met Pelgrimage (1992) zijn beste roman, een verhaal over een curie-kardinaal op zoek naar zijn wortels.

* De lichtwachter (1993) van de rooms-katholiek Pieter Nouwen is een roman waarin een vuurtorenwachter de metafoor is voor Jezus Christus, het licht der wereld.

* Mance ter Andere tenslotte veroorzaakte met twee boeken een forse morele deining in de Nederlandse christelijke pers en heeft misschien alleen daarom al recht op een plaats binnen de moderne christelijke literatuur. In zijn roman Als een pleister van de rauwe huid (1993) vereffende hij een rekening met de dominantie van een vader en van een kerk. De rand van het heelal (1995) werd op verzoek van een christelijk convent van uitgevers en boekhandelaren geschreven om te dienen als christelijk boekenweekboek. De novelle werd echter geweigerd toen bleek dat Mance ter Andere zijn hoofdfiguur aanvankelijk in een godsverduistering plaatste en hem liet protesteren tegen een gesloten hemel. Vooral de receptie van het werk van Mance ter Andere toonde aan dat de conservatieve afdeling van de reformatorische Nederlandse kerken nog een flink stuk wereldmijding te overwinnen heeft. (Mance ter Andere is overigens de enige christen- 
schrijver van naam die in de compositie van zijn romans en verhalen gebruik maakt van post-modernistische trucages als perspectiefverschuiving. $)^{3}$

\section{Essays}

In de golf van biografieën die in Nederland de laatste tien jaar zijn verschenen, had ook de christelijke literatuur haar aandeel. Henk van der Ent schreef de biografie van de dichteres Jacqueline van der Waals (Van der Ent, 1981), G. Puchinger publiceerde biografieën van politici en een biografische schets van de dichter Geerten Gossaert (Puchinger, 1987), J.W. Schulte Nordholt schreef een biografie van de Amerikaanse president Woodrow Wilson (Schulte Nordholt, 1989), Niek van der Heide van de romanschrijfster Wilma Vermaat (Van der Heide, 1992), Hans Werkman van de dichter Willem de Mérode en de romanschrijver Bé Nijenhuis (Werkman, 1983, 1991, 1995b), Michel van der Plas van de dichter Guido Gezelle en van de koopman-schrijver Alberdingk Thijm (Van der Plas, 1990, 1995) en Anne Schipper publiceerde voorstudies uit de biografie over de protestants-christelijke literatuurcriticus C. Rijnsdorp waaraan hij werkt. Ik reken deze biografieën tot de christelijke literatuur, omdat uit deze boeken blijkt dat de schrijvers door hun eigen christelijke achtergrond geholpen werden het christelijk perspectief van de gebiografeerde te doorgronden.

Oudere christelijke essayisten als Ad den Besten, J.W. Schulte Nordholt en Guillaume van der Graft hebben de laatste tien jaar weinig meer aan de essayistiek binnen de Nederlandse christelijke literatuur bijgedragen. Schulte Nordholt en Van der Graft bundelden hun essays over literatuur en aanverwante terreinen (Van der Graft, 1989; Schulte Nordholt, 1992). De eminente kenner van de literaire 17e eeuw, prof. dr. Leen Strengholt, overleed in 1989, 58 jaar oud. Daarmee kwam een einde aan een reeks uiterst leesbare essays over 17e-eeuwse dichters (Strengholt, 1990).

De christelijke literatuur heeft in de jaren negentig maar enkele essayisten in voorraad, en sommige van hen schrijven slechts druppelsgewijs: Sybe Bakker, die zich aangetrokken voelt tot literatuur van Joodse Nederlanders (Bakker, 1992), Bert Hofman, gespecialiseerd in de 16e eeuw (Hofman, 1993), de Gossaert-deskundige Jaap de Gier (De Gier, 1982).

3 De beide discussies werden samengevat door Dirk Zwart (1994:96-99 en 1995:8793) en door Hans Werkman (1995a:37-39). 


\section{Literatuurkritiek}

De christelijke literatuurkritiek wordt naar haar aard frequent beoefend door Hans Ester in het dagblad Trouw, die vooral Zuidafrikaanse en Duitse literatuur bespreekt, Hans Werkman in het Nederlands Dagblad en Woordwerk (Werkman 1982, 1989, 1990, 1994), Mieke Wilcke-van der Linde in het Nederlands Dagblad, Dirk Zwart in het Centraal Weekblad en Bloknoot en Tjerk de Reus in Koers en Bloknoot.

Wat is eigenlijk christelijke literatuurkritiek? T. van Deel, literatuurcriticus van het voormalig christelijke dagblad Trouw, gelooft er niet in, maar hij karikaturiseert haar eerst. Hij zei: "Een goed boek is veel te gecompliceerd om direct met je levensbeschouwelijke vliegenmepper klaar te staan" (Diepstraten, 1982:29). Aan de hand van een voorbeeld maak ik duidelijk wat Van Deel bedoelt.

Sybe Bakker attendeerde aan het slot van een essaytje de Joodse dichteres Judith Herzberg eens op haar ook vaak wanhopige bijbelse collega Asaf, die het visioen van Sion in het oog hield (Bakker, 1985:2-5). T. van Deel reageerde hierop. Hij vond dat de "volstrekt aanmatigende verwachting" van Bakker getuigde "van een schokkend gebrek aan begrip" en dat "zulke stichtelijke verwachtingen eigenlijk een subtiele vorm van laster" zijn (Van Deel, 1985; Werkman, 1989:100-102). Hij bedoelde dat de essayist de besproken dichter niet in haar waarde had gelaten, maar aan haar literaire deur was komen zeuren om met hem "kerk te gaan".

Er bestaat inderdaad een soort van kritiek die de niet-christelijke literatuur zonder meer met bijbelteksten wegmept. Daartegen wil ook ik protesteren. Maar Van Deel schoot naast het doel, want Sybe Bakker hechtte zijn opmerking aan een essay waarin hij het gedicht van Herzberg integer geïnterpreteerd had. Ik meen dat zo'n persoonlijk-religieuze toevoeging de meerwaarde van christelijke literatuurkritiek kan zijn.

Het kan ook veel subtieler. Door de weergave van een inhoud alleen al kan een criticus zijn eigen identiteit bloot geven. Het kan ook voorkomen dat zijn kritische frons heftig is, als hij bijvoorbeeld uitlegt dat in de romans van Maarten 't Hart de Bijbel slechts schijnbaar bestreden wordt, omdat 't Hart de Bijbel meestal citeert in gecoupeerde of verwrongen vorm. Mag dit in een literatuurkritiek? Ik meen van wel, mits een kritiek integer en kwaliteitsvol is en geen preek wordt. Een literatuurkritiek moet het besproken werk geheel recht doen. Maar de criticus mag zichzelf ook recht doen door zichzelf te zijn. Waarom zou T. van Deel wel zichzelf mogen zijn en Sybe Bakker niet?

Judith Herzberg zelf vatte het essaytje van Bakker goed op. Ze schreef hem, al voordat de discussie losbarstte, een vriendelijk dankbriefje. Soortgelijk 
reageerden Maarten 't Hart, Marga Minco, Guus Kuijer, Leo Vroman en anderen op literatuurkritieken die in een waarneembaar christelijk perspectief geplaatst waren.

Wam de Moor heeft jarenlang geschreven voor het rooms-katholieke opinieblad De Tijd. Over deze periode schreef hij: "Mij is nogal eens verweten dat ik een door de kleur van dat blad getekende visie zou hebben op literatuur" (De Moor, 1994:10-11). Hij verdedigde zich min of meer tegen dit verwijt. Maar heeft een katholiek gekleurde literatuurkritiek niet evenveel recht van bestaan als een existentialistisch of postmodernistisch gekleurde literatuurkritiek?

De Moor vervolgde: "Ik heb bij mijn weten altijd over literatuur geschreven vanuit belangstelling voor de literatuur zelf en de menselijke waarden die zij vertegenwoordigt." Dit vind ik een mooie samenvatting van de taak van de literatuurkritiek. Artistieke en menselijke waarden komen daarin samen tot gelding en staan in wisselwerking met elkaar. Ik wens geen ethisch betoog te houden als ik een roman bespreek. Ik wens ook geen strikt literatiteitsbetoog te houden. Niet een ivoren studeerkamer, maar het léven wil ik ontdekken in literatuur. Ik wens er als literatuurcriticus vanuit het leven op te reageren. Natuurlijk is dat mijn leven, maar die omstandigheid kan mijn kritische werk kleur en karakter geven, op voorwaarde dat ik kwaliteit lever. Dat Bemlef en Mulisch en Minco mij zo dicht op de huid zitten, komt juist doordat zij in literaire vorm met een visie op het leven komen. Aan het gesprek daarover wil ik meedoen, vanuit mijn eigen pakket van zowel literaire als levensbeschouwelijke waarden.

Ik kan me geen literatuurcriticus voorstellen die niet voortdurend in gesprek is met mensen, dat wil dus in dit verband zeggen: met de mensen in de roman of de dichtbundel en met de auteur die hen verwekt heeft. Het kan niet anders of daarin spreekt mee wat de criticus ten diepste zelf gelooft over de grote vragen van leven, liefde en lijden.

De vernieuwde aandacht voor de ethiek in de literatuur en de literatuurkritiek (Mooij, Rijnsdorp, Nuis) geeft ook de christen-literatuurcriticus moed om zichzelf te zijn in zijn kritieken.

Ik wil de eisen die ik stel aan een christelijke literatuurcriticus nog even op een rij zetten.

* Een christelijke literatuurcriticus moet in de eerste plaats begripsvol, integer en evenwichtig lezen en beoordelen. Wie het boek dat hij leest geen recht doet, wie aan vriendjespolitiek doet of alleen maar gal braakt, die is het vak van criticus niet waard, en dat geldt dubbel en dwars de 
christen-criticus, die immers niet alleen een hoge literaire, maar ook een hoge ethische standaard behoort te koesteren.

* In de tweede plaats moet de christen-criticus niet overal zijn geloof bij slepen. Hij is geen hulpprediker. "Het hart van de wijze kent tijd en wijze", zegt de Prediker (8:5).

* In de derde plaats verkeert de christen-criticus in de prettige omstandigheid dat hij de Bijbel kent, en dat is alleen al technisch een groot voordeel. De romans van Maarten ' $t$ Hart en de verhalen van Maarten Biesheuvel houden honderden blinde plekken voor critici die wat Bijbelkennis betreft een blinde vlek hebben. Het aantal van die geseculariseerde critici neent toe.

* In de vierde en belangrijkste plaats zal een christen-criticus in gesprek willen zijn met de auteur, terwille van het boek, terwille van de auteur, terwille van zichzelf, terwille van zijn lezers. Dat kan soms op een twistgesprek uitdraaien, en waarom ook niet?

Eén voorbeeld slechts. In de grote, boeiende en knappe roman De ontdekking van de hemel (1992) van Harry Mulisch wordt de wet het ultieme genoemd in de relatie tussen God en mens. De roman is een typisch oud-testamentische roman. Onno Quist geeft zijn zoon Quinten op lange wandelingen uitvoerig catechisatie over het Oude Testament van de Bijbel. Ik heb in geen enkele bespreking van deze roman gemerkt dat iemand hier een vinger bij legde. Lange wandelingen door Rome en door Jenuzalem, en waar is in 's hemels naam Jezus, de ultieme in de relatie tussen God en mens? Mulisch slaat Hem gewoonweg over. Hij pleegt een merkwaardige reductie op een werkelijkheid. In Rome, in Jeruzalem is Jezus Christus uitgewist alsof Hij soft-ware was. Ik denk dat alleen een christen-criticus zoiets merkt en het van een commentaar kan voorzien.

Maar laten we het ook breder zien: geen enkele literatuurcriticus mag zichzelf ontvluchten in steriele kritieken. Anders wordt hij een houtenklaas die op de ingeblikte muziek van voorgeprogrammeerde literaire regels recensies uit een computer hamert. Men mag, men moet zelfs, ook in de literatuurkritiek, een vent zijn die voor een standpunt staat.

\section{Ten slotte}

Ik wil afsluiten met twee citaten van Heinrich Böll. Hij begon zijn kleine essay "Roos en dynamiet" met een misverstand:

Het is roerend maar helaas ontoelaatbaar het zo voor te stellen als bestond er zo iets als een christelijke roman. De christenen verwachten traditiegetrouw 
van een roman die door een christen geschreven is de literaire bevestiging van de geloofswaarheden.

Ik hoop dat ik in dit artikel iets tegen dit misverstand heb ingebracht. Met het tweede citaat uit hetzelfde essay ben ik het van harte eens. Het bevat een noodzakelijke opdracht voor de christelijke literatuur in al haar genres en facetten:

... hoe meer een christen zich als kunstenaar concentreert op stijl en expressie, des te christelijker wordt zijn werk. De taal is een geschenk van God, een van de grootste, want God heeft zich, toen Hij zich openbaarde, altijd van de taal bediend (Böll, 1975:7).

\section{Bibliografie}

Bakker, Sybe. 1985. De meeuwen van Judith Herzberg: gedachten bij een gedicht. Woordwerk, 2 (8):2-5, maart.

Bakker, Sybe. 1989. Christelijke literaire kritiek nù. In: Hofman, Bert (red.), Draagvlak - christelijke literatuur tegen het einde van de twintigste eeuw, themanummer Woordwerk, 7 (27). Werkendam : De Schans, p. 115-124.

Bakker, Sybe. 1992. Vuurproeven: Over literatuur. Barneveld : De Vuurbaak. Bakker, Sybe. 1993. Christelijk proza?: Een reaktie. Bloknoot, 5:69-71, juni. Böll, Heinrich. 1975. Roos en dynamiet. Amsterdan/Brussel : Elsevier.

Bomhoff, J.G. 1988. De kleine terreur van de zogenaamde neutraliteit. Trouw, 12 juli (herdruk uit Wending, dec. 1953).

Bouwers, Lenze L. 1985. Rondelen. Amsterdam : Querido.

De Gier, J. 1982. Stichtelijke en onstichtelijke experimenten: Een onderzoek naar Geerten Gossaerts dichterlijke ontwikkeling en de samenstelling van zijn poëziebundel. Utrecht : HES.

De Moor, Wam. 1994. Een Hollands orakel. Over Maarten 't Hart. Amsterdam : De Arbeiderspers.

Diepstraten, Johan. 1982. In gesprek met T. van Deel. Bzzlletin 100: De literaire kritiek. Den Haag : Bzztôh. p. 27-31, 63.

Ester, Hans. 1994. Cultureel geheugenverlies. Trouw, 22 okt.

Geerds, Koos. 1994. Gods element. Maatstaf, 3 (4):84-85.

Gerhardt, Ida G.M. 1992. Verzamelde gedichten. Amsterdam : Athenaeum / Polak \& Van Gennep.

Goedegebuure, Jaap. 1993. Een naamlooze werkelijkheid. HP/De Tijd, 19 nov.

Hofman, Bert. 1984. Literatuur met de Bijbel. Kampen : Kok.

Hofman, Bert. 1993. Liedekens vol gheestich confoort: een bijdrage tot de kennis van de zestiende-eeuwse Schrifturlijke lyriek. Hilversum : Verloren. 
Jansen, Thijs e.a. 1994. De lezer als burger: over literatuur en ethiek.

Kampen : Kok Agora.

Knol, Henk. 1994. Ander hooglied. Ede : eigen beheer.

Komrij, Gerrit. 1987. De Nederlandse poëzie van de 19de en 20ste eeuw in 1000 en enige gedichten. Amsterdam : Bert Bakker.

Kruithof, Jacques. 1986. Het literair klimaat 1970-1985. Amsterdam : De Bezige Bij.

Kuijper, Jan. 1983. Bijbelplaatsen. Amsterdam : Querido.

Lievaart, Inge. 1994. Een kring in stil water. Kampen : Kok.

Mooij, J.J.A. 1979. De motivering van literaire waardeoordelen. Tekst en lezer. Amsterdam : Athenaeum-Polak \& Van Gennep.

Mooij, J.J.A. 1992. Het primaat van de ethiek. Frame - tijdschrift voor literatuurwetenschap, 7 (2):70-75.

Nuis, Aad. 1989. Een stem in je hoofd-Over literatuur en literatuurkritiek. Utrecht : Het Spectrum.

Puchinger, G. 1987. Inleiding. In: Gerretson, C. Verzamelde werken, deel VII. Baarn : Bosch \& Keuning.

Rijnsdorp, C. 1966. De moderne roman in opspraak. Kampen : Kok.

Rozema, Hilbrand. 1993. Lemelerberg. Woordwerk, 11 (42):34, juni.

Schulte Nordholt, J.W. 1989. Woodrow Wilson: een leven voor de wereldvrede. Amsterdam : Meulenhoff.

Schulte Nordholt, Jan Willem. 1992. Het woord brengt de waarheid teweeg. Kampen : Kok.

Schulte Nordholt, Jan Willem. 1994. Aan mijn tongval te horen. Baarn : De Prom.

Smit, Berta. 1993. Juffrou Sophia vlug vorentoe. Kaapstad: Quellerie.

Smit, W.A.P. 1926. Onze verhouding tegenover kunst en schoonheid. Opwaartsche wegen, 4 (9):335-348.

Smit, W.A.P. 1991. Feesten van 't jaar en andere gedichten. Kampen : Kok.

Strengholt, L. 1990. Uit volle schatkamers: opstellen over literatuur.

Amsterdam : Buijten \& Schipperheijn.

Van Deel, T. 1985. Tijdschriften. Trouw, 2 mei.

Van der Ent, Henk. 1980. Geloven in gedichten. 's-Gravenhage : Boekencentrum.

Van der Ent, Henk. 1981. Jacqueline E. van der Waals: haar leven en werk. Nijkerk : Callenbach.

Van der Ent, Henk. 1986. Waarom christenen niet kunnen schrijven. Hervormd Nederland Magazine, 12 juli.

Van der Ent, Henk. 1989. Christelijke literatuur bestaat niet. In: Hofman, Bert (red.). Draagvlak - christelijke literatuur tegen het einde van de 
twintigste eeuw, themanummer Woordwerk, 7 (27). Werkendam : De Schans. p. 69-73.

Van der Ent, Henk. 1990. "De kapitale C". In: Woordwerk, 8 (29):50-54, maart.

Van der Graft, Guillaume. 1989. Verzameld vertoog. Baarn : De Prom.

Van der Graft, Guillaume. 1993. De hondewacht. Baarn : De Prom.

Van der Heide, Niek. 1992. Mijn voeten hebben Zijn spoor gevolgd. Over leven en werk van de schrijfster Wilma. Leiden : J.J. Groen en Zoon.

Van der Plas, Michel. 1990. Mijnheer Gezelle: Biografie van een priesterdichter. Tielt/Baarn : Lannoo/Anthos.

Van der Plas, Michel. 1995. Vader Thijm: Biografie van een koopmanschrijver. Tielt/Baam : Lannoo/Anthos.

Van Doorne, J. 1975. Trouw, 19 juli.

Van Woudenberg, René. 1989. Werken met woorden - fundamenten en functies. In: Hofman, Bert (red.) Draagvlak - christelijke literatuur tegen het einde van de twintigste eeuw, themanummer Woordwerk, 7 (27). Werkendam : De Schans. p. 7-18.

Werkman, Hans. 1982. Een calvinist leest Maarten 't Hart. Baarn : Bosch \& Keuning.

Werkman, Hans. 1983. De wereld van Willem de Mérode. Amsterdam : De Arbeiderspers.

Werkman, Hans. 1989. Gerommel van Büch tot Bommel. Kampen : Kok.

Werkman, Hans. 1990. Boek werken. Barneveld : De Vuurbaak.

Werkman, Hans. 1991. De Mérode en de jongens. Baarn : De Prom.

Werkman, Hans. 1994. "De God in mij moet sterker worden": interview met Oek de Jong. Woordwerk, 12 (46):2-14, juni.

Werkman, Hans. 1994. Kees \& co. Bameveld : De Vuurbaak.

Werkman, Hans. 1995a. De hoeders en de rand. Woordwerk, 13 (49):37-39, maart.

Werkman, Hans. 1995b. Spitten en [niet] moe worden: leven en werk van Bé Nijenhuis 1914-1971. Kampen : Kok.

Wind, Harmen. 1994. Tijden. Woordwerk, 13 (45):32, maart.

Zaal, Wim. 1982. In ons hart zijn wij een luibuis. Elseviers Magazine, 17 juli.

Zijlstra, Jaap. 1991. Ik zie je zo graag. Baam : De Prom.

Zwart, Dirk. 1993a. Christelijk proza? Bloknoot, 4, febr.

Zwart, Dirk. 1993b. Reacties op “Christelijk proza?" Bloknoot, 5, juni.

Zwart, Dirk. 1994. Professor Douma en vader Ter Andere. Bloknoot, 8, mei.

Zwart, Dirk. 1995. Een standbeeld voor Rein. Bloknoot, 11, febr. 
